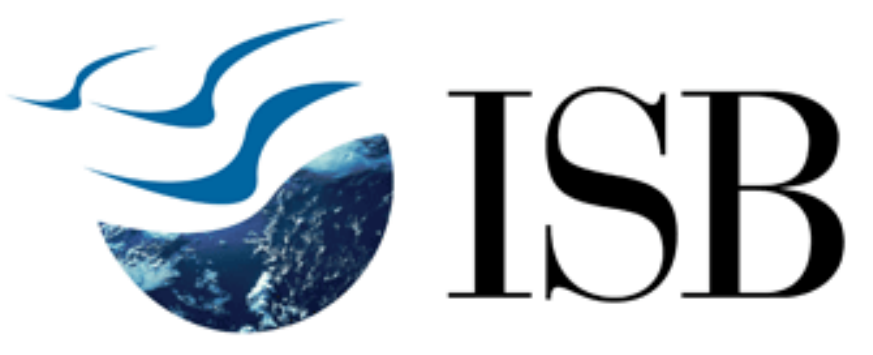

\title{
Insecure Advantage? Markets for Technology and the Value of Resources for Entrepreneurial Ventures
}

\author{
Anand Nandkumar
}

and

Ashish Arora

http://eprints.exchange.isb.edu/265/

Working Paper

Indian School of Business

2010 


\title{
Insecure Advantage? \\ Markets for Technology and the Value of Resources for Entrepreneurial Ventures
}

\author{
Ashish Arora \\ Fuqua School of Business, Duke University and NBER \\ 1 Towerview Drive, Durham, NC 27708-0120 \\ Tel:919-660-7746 \\ Fax: 919-684-2818 \\ ashish.arora@duke.edu, \\ Anand Nandkumar ${ }^{1}$ \\ Indian School of Business \\ Gachibowli, Hyderabad, India 500032 \\ Tel: +91-40-23187163 \\ Fax: +91-40-23187032 \\ anand_nandkumar@isb.edu
}

Keywords: RBV, markets for technology, entrepreneurship, contingent value of resources, performance

\footnotetext{
${ }^{1}$ Corresponding author. This paper is based on a chapter of Nandkumar's $2008 \mathrm{PhD}$ dissertation at the Heinz College, Carnegie Mellon University. The paper has improved in response to comments from anonymous reviewers of the Journal. We are also grateful to seminar participants at Duke, UCLA, and Emory for helpful comments.
} 


\begin{abstract}
:
We study how the impact of capabilities for performance is contingent upon the environment. Using a novel dataset of Information Security startups, we study how markets for technology change the relative impact of technology and marketing capabilities on performance. Since internal technical effort enables firms to generate technology inputs instead of acquiring it from the market (substitute), a greater supply of technology diminishes the importance of technical ability as a source of competitive advantage. Moreover, since marketing capability complements technology inputs, a greater supply of technology enhances the impact of marketing capability on performance.
\end{abstract}


The resource-based view (RBV) of the firm argues that competitive advantage derives from resources (or capabilities) of firms that are valuable, rare, non-substitutable, and inimitable (Barney, 1991; Rumelt, 1991; Wernerfelt, 1984). However, as Barney (2001) has noted, whether a capability bestows competitive advantage is contingent depends upon the environment, a point that is acknowledged but whose implications are in sufficiently appreciated. In this paper we argue that the development of input markets can change the sources of competitive advantage for a firm.

Following Amit and Shoemaker, (1995) and Helfat and Lieberman, (2002), we define capability as a firm's ability to deploy resources for a desired result which can include the creation of new resources, or inputs that are required to produce the end product or service. For instance, technical capability enables a firm to develop new technology, or more generally, higher technical capability lowers cost of internally developing technology. Thus, in this paper, we conceive of a capability as reducing a firm's cost of producing an input. ${ }^{2}$ Of course, this mapping from capabilities to inputs is a simplification, but is a useful one for understanding how the value of capabilities is contingent upon the environment.

What happens when a market develops for an input that was hitherto solely internally developed? Paradoxical as it may seem, the growth in the market for an input makes it more valuable but, as we show in this paper, the capability to generate the input may also become less important as a driver of a firm's competitive advantage. On the other hand, other complementary inputs and the associated capabilities may become more important in driving firm performance. Furthermore, the relationship between two resources may itself be contingent upon environmental conditions.

Technological capability is widely believed to be a source of competitive advantage, principally because since the growth of corporate R\&D labs in the twentieth century, firms have typically relied upon internally developed technology. The development of a market for technology has two effects. First, a firm with superior technical capability can exploit it be developing and licensing technology to others with superior production and

\footnotetext{
${ }^{2}$ More formally, greater capability reduces the average and marginal cost to the firm of producing the input. - 3 -
} 
marketing capability, rather than by using the technology to compete in the product market. For firms with weak production or marketing capability, therefore, a market for technology can increase the value of its technical capability. This aspect of markets for technology has been extensively studied in the literature (e.g., Arora, Fosfuri, and Gambardella, 2001a; Gans, Hsu, and Stern, 2002).

Our empirical analysis highlights the hitherto under-appreciated second effect: Technology markets allow firms to in-license and build upon external technology instead of relying solely upon internal capability. The net effect is to reduce the importance of internal technology but increasing that of marketing capability for firm performance.

Our contribution is to clarify the effect of the growth of a market for an input, such as technology, on the importance of the associated capability and of capabilities that complement it, such as marketing, for firm performance. Our paper contributes to the small but important empirical literature on how contingencies in the environment influence the relative importance of a firm's capabilities (Brush and Artz, 1999; Zajac, Kraatz, and Bresser, 2000; Miller and Shamsie, 1996; Katila and Shane, 2005). A secondary contribution of this paper is to empirically highlight that the relationship between two distinct types of capabilities, viz. technical and marketing, is itself conditioned by the supply of technology.

This paper is organized as follows: the following section reviews literature and develops our hypotheses. We then briefly discuss the ISM and the data sources used in this paper which, is followed by our empirical analysis and findings. We conclude with a discussion of our findings.

\section{HYPOTHESIS DEVELOPMENT}

Our main contribution to the strategy literature is to clarify how the impact of capabilities in providing competitive advantage is contingent upon the environment in which firms operate. Firms use inputs, conceived of broadly to include not just material inputs such as labor and machines, but also technology and marketing and sales. Some of these inputs are produced by the firm itself, using capabilities and resources. At the heart of RBV is the premise that firms differ in their resources and capabilities, which therefore are the source of long 
run competitive advantage (Barney, 1986, 2001; Dierickx and Cool, 1989; Penrose, 1959; Lippman and Rumelt, 1982; Wernerfelt, 1984; Rumelt, 1991; Amit and Schoemaker, 1993; Dosi and Teece, 1993).

The RBV builds on the Ricardian insight that land, which is inelastically supplied, can garner supernormal profits even in a competitive market. The RBV framework extends this logic by assuming that factors other than land may be inelastic in supply (Peteraf, 1993) because some capabilities take time to be developed, and neither the capability themselves nor the inputs that can be generated using them can be acquired from the market (Barney, 1991). However, as markets for inputs, in our case, technology markets, develop, capabilities that are important to develop such inputs become less important for a firm's competitive advantage, although the input per se may become more valuable. For instance, though land supply may be fixed, neither its ownership nor the possession of associated capabilities to make use of it more efficiently automatically confers competitive advantage for its owner when there is a market for land. A market for land implies that land is still valuable, but much less of a source of competitive advantage. However, this will make other inputs that complement land and the associated capabilities more valuable.

Similar arguments apply, mutatis mutandis, to technology. A market for technology reduces the importance of technical capability as a source of competitive advantage for firms that use it as input but enhances the importance of other sources of advantage, such marketing capability.

We thus build on work in the strategy and economics literature that demonstrate how a certain type of resource or a capability drives long term performance and how contingencies in the environment moderate the value of such resources or capabilities. A growing body of empirical literature shows that firm-specific factors explain the bulk of the variation in the profitability between firms. For instance, Hansen and Wernerfelt (1989) find that organizational factors explain about twice as much variance in profit rates as economic factors. While Rumelt (1991) also provides similar evidence, McGahan and Porter (1997) find that industry-specific effects explain about 32 percent of the variation in profitability. This variation is associated with differences between firms in the resources and capabilities that they use to generate profits. Consistent with this view, several industry studies in economics and strategy literature demonstrate how a particular type of a resource or a capability can be a source of competitive advantage for firms (Robins and Wiersema, 1995; Henderson and -5 - 
Cockburn, 1994; Makadok, 1999; Barney and Arikan, 2001), although the precise nature of the capability that generate abnormal returns varies.

Several empirical studies of entrepreneurship suggest that certain unique capabilities, acquired primarily through work experience, drive the long-term success of startups (Helfat and Lieberman, 2002). This stream of work typically demonstrates the importance of both technical and complementary commercialization capability. Like the broader literature that deals with how capabilities bestow long term competitive advantage on firms, the precise nature of the capability that drive success varies by the industry context studied. For instance, technical ability was found to be crucial for success in the shipbuilding (Thompson, 2005), automobile (Klepper, 2002; Carroll et al., 1996), and TV industries (Klepper and Simons, 2000). Complementary capability is also found to be important, although the precise nature of the complementary capability differs between studies. Mitchell $(1989,1991)$ shows that marketing capability was critical for success in the medical diagnostic imaging industry. Tripsas (1997), shows that superior complementary capability in the typesetting industry even enabled some technologically underperforming firms to succeed. Simply put, different types of capabilities have been shown to be important for the success of entrants in different studies. If indeed the value of capabilities is contingent on the environment in which a firm operates, as we show in this study, this can at least partially explain the diversity found in the literature. We thus contribute to the entrepreneurship literature by showing how the relative value of different types of capabilities that enable startups to succeed in a new industry is contingent on the environment.

As Barney (1991) points out, the environmental context within which the resource is applied influences whether the resource confers competitive advantage, but empirical studies that examine this idea are rare, with a few notable exceptions. Brush and Artz (1999) examine how the contingent combination of search qualities, prior experience, and credence of veterinary physicians influences success in the veterinary medical services industry. Zajac, Kraatz, and Bresser (2000) study about 4000 savings and loan institutions and find that the effectiveness of strategies depends on how the organizational resources interact with local and general market conditions. Miller and Shamsie (1996) show that knowledge-based resources in the Hollywood film industry are more valuable for performance in uncertain environments, whereas property-based resources, such as long-term -6 - 
contracts, are more useful in stable environments. Katila and Shane (2005) examine how market size, manufacturing intensity, and the availability of finance affect the performance of MIT technology startups. We focus on a different type of contingency: How a market for technology conditions the importance of technical capability and of a complementary capability, marketing, for the performance of entrants into a new industry.

Several studies have dealt with how new technology can be disruptive to incumbents. These studies often focus on why incumbents fail to recognize the new technology quickly (e.g., Utterback and Abernathy, 1975; Foster, 1986) or on the apparent inability of incumbents to use the new technology effectively (Henderson and Clark, 1990; Leonard-Barton, 1992; Hannan and Freeman, 1984). We focus instead on how the market availability of technical inputs shifts the relative importance of technical and marketing capability. Although our empirical analysis is based exclusively on startups, our story applies both to startups and incumbents. Focusing on startups, however, enables us to distinguish our story from the effects of possibly disruptive technical advances on incumbents.

Our work also relates to the stream of work that deals with markets for technology. Prior work in this stream typically deals with how markets for technology influence firm strategies for the commercialization of technology (Arora, Fosfuri, and Gambardella, 2001a; Gans, Hsu, and Stern, 2002). We however focus on another relatively under studied implication of the existence of markets for technology. The existence of markets for technology means that potential entrants to an industry do not need to develop their own technology but instead can in-license externally developed technology, thereby promoting entry into an industry (Arora, Fosfuri, and Gambardella, 2001b; Lieberman, 1987 and 1989). The net effect is to reduce the importance of a capability that is used to generate such technology but increasing the importance of complementary inputs and its associated capabilities such as marketing capability for firm performance.

More generally, our paper also relates to drivers of firms' technology strategies. For instance, Helfat (1997) shows that a firm's knowledge about complementary technologies also determines how that firm reacts to a contingency. Using a dataset from the petroleum industry, Helfat (1997) shows that a firm's strategic response to oil shocks in the mid 1970s and 80s varied based on their levels of complementary knowledge firms with greater complementary technological knowledge and physical assets undertook larger amounts of -7 - 
R\&D on coal conversion. Similarly, Arora and Ceccagnoli (2006) show that whereas firms with complementary manufacturing capability derive patent innovations to facilitate commercialization, those lacking such capability use patents to facilitate licensing. Our paper complements this by showing that the availability of licenses increases the importance of (complementary) marketing capability but reduces the importance of (substitute) technical capability. ${ }^{3}$

Following the literature, we assume that marketing and technical capability are complements. However, although we theorize about how external technology supply affects the importance of marketing and technical capabilities, existing theory provides little insight on how it should affect the relationship between marketing and technical capabilities. Accordingly we empirically explore this issue but do not develop hypotheses on this. ${ }^{4}$

\section{Hypotheses}

We assume that a firm requires two types of inputs, marketing and technology, which are complementary in that the marginal payoff from the technical input is greater if the firm also has greater marketing input. We assume that a startup is endowed with a given marketing capability and technical capability. These capabilities condition the cost of producing the marketing input and technical input respectively. However, whereas marketing can only be produced in-house, firms can use a combination of self-generated technology (internal technology, henceforth) and technology licensed-in from a licensor (external technology, henceforth). We assume that internal and external technologies are close substitutes and that startups can (partially) substitute internal technology with external technology. To anticipate our empirical setting, a firm could develop an encryption algorithm internally and then implement it in a software system to provide secure communication (internal technology), or it could license-in an existing encryption algorithm and use it with internally developed software to provide secure communication software (internal and external technology). The price of external

\footnotetext{
${ }^{3}$ Strictly speaking, it is internally developed technology which is a substitute for external technology, not technical capability.

${ }^{4}$ We thank an anonymous reviewer for raising this point. 
technology depends on competition among technology suppliers, so that more suppliers results in a lower price of external technology. ${ }^{5}$

This is consistent with available evidence, most notably from the chemical industry. Using data on twenty - four chemical products, Lieberman $(1987,1989)$ reports that patenting by outsiders was associated with a faster decline of product price, suggesting that patenting by outsiders encouraged entry in the product market. Arora, Fosfuri, and Gambardella (2001b) find, based on data on chemical plants built during the 1980s in 38 countries, that an increase in the number of technology suppliers increases investment, especially that based on technology licensed from the outside.

\section{Markets for technology and technical capability}

All else equal, firms that have superior technical ability should have a lower cost of producing technology in-house. This implies that firms with higher technical capability, all else equal, should also perform better. Several studies in the entrepreneurship literature find that technical ability is a source of competitive advantage. For instance, in the shipbuilding industry, experience in fabrication was a key source of competitive advantage (Thompson, 2005), and in semiconductors, spin-offs outperformed other entrants due to superior technical expertise (Klepper and Sleeper, 2005). This leads to our first hypothesis, formally stated below:

\section{H1: Technical ability is valuable and firms with superior technical ability perform better.}

Since internal technology and external technology are substitutes, an increase in the price of external technology should cause firms to increase internal technical effort to internally produce technology to substitute for more expensive external technology. However, since firms with superior technical capability have a lower cost of technical effort, they can substitute internal technical effort for external technology more effectively. Thus, a fall in the price of external technology benefits firms with superior technical ability less than it benefits

\footnotetext{
${ }^{5}$ In a fully specified model, the price of external technology would also depend on the number of buyers in the product market. In an earlier version of this paper we had solved a model that considered the price of external technology to be an endogenous parameter determined by the number of firms in the product market. 
firms with inferior technical ability. This implies that although technical capability enhances performance per se, the advantage diminishes as external sources of technology become more plentiful.

However, insofar as internal technical ability also provides absorptive capacity, there is a potentially offsetting effect: an increase in the supply of technology increases the value of absorptive capacity, thereby benefiting technically more capable firms to a greater extent. Though plausible, we believe the absorptive capacity effect is likely to be small in our setting. Most, if not all, of the entrants in the information security industry have a basic grounding and experience in information technology and information security technologies (Giarratana, 2004). In our sample, about 53 percent of the startups were from the ICT (including the ISM industry itself). In addition, about 51 percent of the startups had one or more founders with a technical degree (PhD. in engineering or CS or EE masters). In our regressions, we control separately for the technical education and the industry experience of the principal founder (founder with the greatest experience among all focal founders).

Moreover, in many instances, the technology is licensed in ways that make it easy to use, for instance, by embodying it in software which is licensed to vendors. Advances in software engineering mean that the technologies were essentially licensed out as Application Programming Interfaces (API), which have greatly diminished the need for licensees to understand the internal working of the licensed technology.

H2: The importance of technical ability for performance diminishes with an increase in the supply of external technology.

Marketing capability and markets for technology:

Several studies, such as Mitchell (1989), suggest that marketing ability is an important source of competitive advantage for firms. Superior marketing ability should lower the cost of marketing effort. This implies that superior marketing should be a source of competitive advantage and that such firms should be more profitable on an average. We formally state this as a hypothesis below:

H3: Marketing ability is valuable and firms with superior marketing ability perform better. 
Translating a promising technology into a 'killer app', however, requires not only technical ability but also understanding of customer needs (Agarwal et al., 2004). Simply put, marketing and technology are complements. More formally, the marginal payoff of technology is greater if the firm also has greater marketing ability (which lowers the cost of providing the complementary marketing input). A fall in the price of external technology due to greater supply of external technology will therefore benefit firms with higher marketing ability to a greater extent. ${ }^{6}$ Hence, when technology is also externally available, marketing capability may be more important in differentiating a firm from its competitors, and thus be more valuable for performance. Although our hypothesis formally started below applies to marketing capability, in general, a fall in the price of external technology should enhance the value of any capability that complements technology, for performance.

H4: The importance of marketing ability for performance is enhanced by an increase in the supply of technology.

We have assumed that technical ability and marketing ability are complements but have not explored the sources or drivers of this complementarity. For instance, Cassiman and Veugelers (2006) find that the complementarity between external and internal technology is present when the firm has a basic research focus but not otherwise. Here we explore whether the complementarity between technical and marketing capability is conditioned by the supply of external technology, as a supplement to the main empirical analysis

Our theory also applies to the case where marketing services can be obtained from the market. If internal marketing and external marketing are substitutes, then an increase in the availability of external marketing services should diminish the relative importance of marketing capability for performance and enhance that of technical capability. Also, since technical ability of a firm complements marketing ability, an increase in the availability of marketing services should increase the relative value of technical ability for performance. We

\footnotetext{
${ }^{6}$ A stylized model with accompanying figures that convey the underlying intuitions behind the hypotheses can be provided upon request. 
lack empirical measures for measuring the extent of a market for marketing services, and cannot explore this empirically.

\section{DATA AND MEASURES}

Our sample consists of 270 startups, followed from the time of entry until 2004 or their exit, whichever is earlier. Of a total of 343 firms that entered the ISM between 1989 and 2004, we exclude 57 diversifying entrants because de novo entrants have very different resources than existing firms entering a new industry. In particular, diversifiers may be able to leverage technical and marketing resources from their existing business in the new market in ways that we cannot measure or capture. Moreover, performance is harder to measure for incumbent producers. For instance, when applied to an existing firm that enters a new market, commonly used measures of performance such as survival may reflect long-term strategy rather than superior performance. For similar reasons, we also exclude 16 startups that were exclusively licensors of technology.

Our unit of observation is a firm-year. From the Corptech directory, we obtained names of all firms that entered ISM between 1989 and 2004. We then used Internet archives (www.archive.org) to manually augment this dataset with information on the submarket of entry. We also hand-collected collected information about up to four founders from Internet sources such as ZoomInfo (www.zoominfo.com), LinkedIn (www.linkedIn.com), Google Archives (www.archives.google.com), Internet Archive (www.archive.org), and the EDGAR database. Finally we also acquired initial size of some startups from Bureau Van Dyck (BvD) database.

The information security market (ISM) is an interesting and rapidly growing industry in its own right. Information security technology dates back to late 1970s, when U.S government-funded military projects were awarded to universities and large defense contractors to secure data transmission. The growth of the Internet greatly increased the demand for this and other types of products such as anti-virus (and later, anti-spam), authentication, and access-control products. This remains an industry experiencing rapid technical change and steady growth.

ISM provides a good test bed because we can not only measure variations in the capabilities of startups but also variations in the supply of external technology, both across different submarkets and over time. As we 
describe below, ISM products are based on different combinations of four basic technologies: encryption, pattern matching, image matching, and single sign-on.

Table 1A shows that each of the eight submarkets in the ISM draws upon different combinations of four basic technologies. For instance, authentication products combine encryption and single sign-on technology. Differences in the extent to which there are independent suppliers, especially universities, for these technologies, provides a source of variation in technology supply across different submarkets.

Table 1B is important for understanding the source of variation that identifies the effect of technology supply. Column 2 of Table 1B shows that licensing in technology is more common in authentication, encryption product, and network submarkets. These submarkets rely upon technologies, such as encryption algorithms, that are codifiable and based on scientific research, and hence tend to be patented extensively. Column 3 shows that authentication, encryption products, and network submarkets are more patent intensive relative to others. Moreover, universities hold a significant proportion of the patents in such areas, as column 5 shows. Furthermore, column 6 indicates significant variation over time in patenting by universities.

\section{<Insert Table 1A and 1B here>}

Variation in the nature of technology, especially its scientific content, means that universities are a major source of innovation in some technologies. University-based innovations tend to be science based, which also makes the innovation easier to articulate and codify, and hence to patent. Consequently, technologies for which universities are a major source of innovation are also well suited for licensing (Arora and Gambardella, 1994; Gambardella and Giarratana, 2007). ${ }^{7}$ For instance, since encryption technology at its core consists of mathematical algorithms, this technology can be patented easily and frequently emerges from universities.

University inventions are often embryonic and require substantial further development, which would imply that using university technology typically requires substantial absorptive capacity (Agrawal, 2006; Jensen and Thursby, 2001). However, in the information security industry, university-invented information security inventions are often developed by the inventors themselves, based on licenses granted to them by their

\footnotetext{
${ }^{7}$ Gambardella and Giarratana (2007) exploit the variation in technology and submarkets to analyze how markets for technology affect an entrant's choice between licensing or developing a product in the ISM. 
universities. The important point is these startups sometimes do not develop products but instead license the technologies to other information security firms in easy-to-use forms, on a non-exclusive basis.

For instance, the Diffie-Hellman encryption algorithm, which was invented at Stanford University, was exclusively licensed to Cylink Corporation, co-founded by UCLA professor Jim Omura. In turn, Cylink developed and licensed encryption technology to others. Similarly, MIT exclusively licensed the RSA encryption technology to RSA Data Security, a startup founded by the inventors of the technology themselves, in exchange for a share in the royalty payments and a one percent stock in the startup. Finally, Certicom, a company that licenses elliptical curve encryption technology, was based on the invention of University of Waterloo professors Scott Vanstone, Ronald Mullin, and Gordon Agnew. ${ }^{8}$

In all three cases these firms licensed technology to other firms, including other information security firms. The key was that the technology was offered in easy-to-use forms. Instead of simply receiving a patent license, buyers got software and tools that they could use to embed the technology in their products. In all, 15 of the 16 firms that are specialist technology suppliers in information security were started up by university professors, commercializing nascent university technology. ${ }^{9}$ In other words, even if university inventions are themselves not ready for commercial use, they often give rise to specialist technology suppliers for information security startups. Thus in the ISM, university technologies flow to the industry through specialized technology suppliers. In many cases, the founders of the specialized technology supplier were themselves the inventors of the university technology, who exclusively licensed the technology from universities for a share in royalty. In other cases, universities exclusively license-out technologies to specialist technology suppliers, which in turn adapted and developed the nascent university technology to suit commercial use.

We now describe our empirical measures in detail.

Performance: We use two measures of performance. Our first measure is failure defined as exit from all submarkets in the ISM that the focal startup may have operated in. Although the use of survival as a measure of performance is common (e.g., Klepper and Simons, 2000; Carroll et al., 1996; Thompson, 2005), it is possible

\footnotetext{
${ }^{8}$ We discuss three examples that explain the role universities as a source of ISM technologies.

${ }^{9}$ There are 28 university startups in the sample, of which 13 entered the product market, and 15 specialized in licensing technology. -14 -
} 
that the decision to exit reflects other strategic considerations unrelated to performance. For instance, inexperienced entrepreneurs may linger on for want of a viable outside option or because of non-pecuniary benefits associated with entrepreneurship (Blanchflower and Oswald, 1998). Another potential issue is that a market for technology may result in a firm with good technology but poor marketing ability to quit the product market and sell or license the technology. ${ }^{10}$

Accordingly, we check the robustness of our results with another measure of performance, namely cashouts, defined as a favorable acquisition or an Initial Public Offering (IPO), whichever was earlier. In supplementary analysis (available upon request) we show that our principal results are robust to using yet another measure of performance, employee growth, defined as the year on year growth in employment for the first three years from the year of entry.

We term a firm as having failed if it ceases to exist or if it enters a "distress sale". ${ }^{11}$ Favorable acquisitions are treated as censored. While the date of acquisition was identified using the Zephyr database, the year of exit was identified as the year in which the focal firm's corporate web site was last available on archive.org, a site that contains historical archives of all Internet web sites.

We assign each startup to a single submarket based on the submarket of entry. The preponderance of firms in our sample operate only in the initial submarket of entry. Insofar as firms do operate in multiple submarkets, this implies that the effective technology supply they face is being measured with error. Classical measurement error will induce an attenuation bias in our estimates, implying that the true effects may be even larger than those reported here.

Technology Supply: Our first measure of the extent of supply of technology is the number of university security patents relevant to the submarket. These represent the stock of ISM patents held by universities and government agencies (lagged one year). We constructed this variable as follows. We collected all ISM patents held by

\footnotetext{
${ }^{10}$ We thank an anonymous reviewer for helpful discussion on this point.

${ }^{11}$ We used two criteria to determine if an acquisition was a distress sale: (1) if the firm was sold for less than \$1 million and (2) if the transaction was an asset purchase, determined from the press release of the acquisition. For instance, if the press release stated that the merger was an "asset purchase", we classified such mergers as a distress sale, e.g., Netopia acquisition of DoBox Inc. http://www.bizjournals.com/sanfrancisco/stories/2002/04/01/daily4.html (last accessed July 27, 2008), Contentwatch acquisition of NetNanny software see http://www.manac.com.au/releases/44/Net_Nanny.pdf (last accessed July 27 $7^{\text {th }}$ 2008). Acquisitions that failed both criteria were treated as a cash-out. A total of 79 firms in our sample were acquired, of which 11 were classified as being distress. 
universities and government agencies. ${ }^{12}$ We assigned each patent to an ISM submarket using a many-to-one US.PTO sub-class - ISM submarket mapping, developed using a method used by Cockburn and MacGarvie (2007).We first identified firms that operate in only one ISM sub-market and had more than 15 information security patents. We then determined the patent sub-classes in which these specialist firms received at least 10 percent of the patents (and at least 2 patents). Each information security patent in that patent subclass was then assigned to the corresponding submarket (see appendix for details). This measure thus varies not only between submarkets but also within a submarket over time.

Universities have been a key source of several ISM technologies that are licensed out to producers by technology suppliers. Several of the technologies were initially developed for US military projects (Giarratana, 2004). Thus university patenting largely reflects faculty research responding to U.S defense and security needs, anticipating rather than responding to private demand.

We acknowledge that our measure of the extent of supply in markets for technology, the number of university patents, is an imperfect proxy for underlying conceptual category, namely the ability of potential entrants to obtain the required technology cheaply and easily. For one, not all commercially licensed technologies are based on university inventions. However, this measurement error would attenuate bias in estimates, biasing against finding an effect. University patents may also be related to underlying technical opportunities. Further, some universities have adopted policies in which inventions are not patented until a licensee is identified, so that university patents may be related to demand growth. In either case, the implication is that the value of internal technology should be higher when technical opportunity is high or demand is growing, not lower, as hypothesized here. Nonetheless, we use a variety of measures to check the robustness of our results, using alternative measures for the supply of technology as well as using detailed submarket level controls, as described in the robustness section later.

\footnotetext{
${ }^{12}$ We searched for all patents in the US.PTO in patent classes 705 (subclasses 50-79), 380, and 726 whose assignee names matched with the universities listed at http://www.utexas.edu/world/univ/state/ (last accessed February 19 2009 ) or any of the names of government agencies listed at http://www.usa.gov/Agencies/Federal/All_Agencies/index.shtml (last accessed February 21st, 2009) that belonged to US.PTO subclasses 726, 380, and 705 (subclasses 50-79). 
Table 2 describes our empirical measures, including those for marketing and technical capability. In accordance with the resource-based view of the firm, we use the resources that the firms are endowed with (rather than those they create) to develop our measures for marketing and technical capability. ${ }^{13}$

Marketing Capability: We measure the marketing capability of startups as the number of sales executives that the startup employed at the time of entry (sales executives, henceforth). We base this measure on information in the CorpTech directory, which lists the top 10 employees of the firm along with their principal function (e.g., finance, sales or marketing, engineering). Since the distribution of the number of sales executives is skewed, we use the $\log (1+$ sales executives $)$. The measure is correlated with other measures of marketing ability. For example, the correlation of sales executives with the number of IT trademarks that a startup obtains in the first three years of operation is $0.42 .{ }^{14}$

Technical capability: We use the number of information security patents assigned to the startup when it was formed, as a proxy for technical ability of the startup. As is standard in the literature, we weight these patents by the number of forward citations received. Virtually all these patents are invented by members of the founding team, and thus represent a good signal of the technical capability of the startup.

Not all types of technologies lend themselves easily to patent protection. Even so, patents can signal whether the firm intends to differentiate itself from others based on its technology. For instance, Check Point obtained the pioneering patent, in 1997, for "stateful inspection" technology widely used in firewalls, but has also relied on a mix of secrecy, copyright, and first-mover advantage to become a market leader in the firewall submarket. ${ }^{15}$ By contrast, Zone Alarm, which produced a widely used firewall product for personal computers and was later acquired by Check Point, has not filed a single patent. Thus, even in submarkets where patents are typically not very effective, patents can be a signal of technical competence. We also use submarket fixed effects in our empirical analysis as an additional guard against this heterogeneity.

\footnotetext{
${ }^{13}$ Our results are stronger if we use measures of technical (lagged yearly stock of security patents) and marketing capability (lagged yearly stock of trademarks) that vary not only by firms but also by year. These results are available upon request.

${ }^{14}$ We get qualitatively similar results even if we used the number of parent IT trademarks as an alternative measure of marketing capability.

${ }^{15}$ Check Point's original patent, US patent \#5606668, has been cited by 247 other patents.
} 
Scale: The literature shows that firms that are larger at time of founding tend to perform better. We measure scale as the number of employees at the time of entry into the ISM. We acquired this variable from corpTech and BvD databases. For 10 startups we are unable to obtain data on entry size.

ISM tenure: We measure tenure from the year the startup was established. It is well known that survival is time dependent - firms that survive for a certain number of years are likely to survive longer (Dunne, Roberts, and Samuelson, 1988; Evans, 1987; Audretsch and Mahmood, 1995; Mata and Portugal, 1994). To allow for nonlinearities, we also include the square of ISM tenure.

Submarket age: It is plausible that firm survival or performance may vary as submarkets grow and mature (e.g., Agarwal and Gort, 2002). We measure submarket age as the number of years since the first firm entered the focal submarket. This variable effectively measures the passage of time, although the starting point differs across submarkets.

Cohort dummies: The demand for information security prior to the Internet was limited and the growth of the Internet provided a great boost to demand, but after the collapse of the Internet bubble, survival for Internetfocused companies likely became harder. Accordingly, we distinguish between three time periods: Prior-to-theInternet (1980-1995), Internet-boom (1996-2000), and Post-bubble (2001-2004).

The performance of startups also depends critically on whether or not the founders are seasoned, knowledgeable about industry, and skilled managers. In particular, university researchers or technology-savvy but business-naïve founders may find it difficult to succeed even in technology-intensive businesses.

Accordingly, we use a variety of controls for the technical and industry experience of founders.

ICT startup $=1$ if the focal firm's principal founder worked for a computer hardware, software, IT consultancy, ISM, or telecommunication firm.

Spinoff $=1$ if the focal firm's principal founder worked for another information security firm.

User startup $=1$ if the focal firm's principal founder worked for a non-ICT-based industry. ${ }^{16}$

\footnotetext{
${ }^{16}$ If there are multiple founders, startups can belong to more than one category.
} 
Founder experience: We measure the work experience (founder experience, henceforth) of the principal founder as the elapsed years from final academic degree to the year of founding the startup. For 10 startups, we were unable to trace the year of final academic degree for the principal founder. ${ }^{17}$

\section{$<$ Insert Table 2 here $>$}

Founding team education and experience controls: In addition, we use four education dummies. These consist of the following binary variables. $\mathrm{PhD}=1$ if one or more founders of the firm had a $\mathrm{PhD}$ degree, Masters $=1$ if one or more founders of the firm had a masters degree (other than masters in computer science or electrical engineering), Bachelors $=1$ if one or more founders of the firm had a bachelors degree (other than bachelors in computer science or electrical engineering), and CS-EE=1 if one or more founders of the firm had a computer science or electrical engineering bachelors or masters degrees.

Total ISM patents (lagged): In some specifications, we also control the total citation weighted and lagged ISM patents relevant to the submarket, as a control for changes over time in technical opportunity.

ISM submarket dummies: In all our empirical specifications we also include 7 submarket dummies for encryption product, network security, authentication, firewalls, antivirus, spam control, and hardware submarkets. Consulting is the residual category.

\section{EMPIRICAL RESULTS}

We begin with a non-parametric analysis of the data. Table 3A shows that while startups with superior technical capability have lower average exit rates, the benefit of technical capability is more marked when technology supply is low. In Table 3A, we classify firms with fewer-than-average security patents as low technical capability, and more than average as high technical capability. Consistent with H1, we see that firms with low technical capability have higher exit rates than high-technical-capability firms. However, while the difference is 15 percentage points (i.e., 26 percent versus only 11 percent) when technology supply is low (Column A), it is only three percentage points when technology supply is high (Column B).

$<$ Insert Table 3A here>

\footnotetext{
${ }^{17}$ In the regressions, we assign these startups sample average for founder size. We were nonetheless able to construct education dummies and work experience dummies for these startups. 
Table 3B shows that although an increase in the supply of technology increases exit, the effect is smaller for firms with higher marketing capability. An increase in the number of university patents increases exit rates by $10 \%$ for firms with low marketing ability, while a similar increase is associated with only a $2 \%$ increase in exit rates for firms with high marketing ability.

The non-parametric analysis in Table 3 supports our hypotheses but does not control for a variety of other factors. Accordingly, we turn to survival analysis. The use of discrete time survival regressions is common in cases where some of the independent variables (e.g., university patents) are time varying and wherein the occurrence of multiple failure events within a time interval (ties) is very high (Martin and Mitchell, 1998; King and Tucci, 2002). In our case, since the data is observed annually, ties are likely. We use discrete time logit regressions, in which the dependent variable takes a value of 1 if the focal firm failed in the period of observation. $^{18}$

\section{<Insert Table 3B here>}

In Table 4, we show only level effects of marketing and technical ability, measured by sales executives and security patents. Since 10 startups do not report initial size, in specification 1, we do not include initial size. In specification 2, we include size but exclude startups that do not report their initial sizes. This specification uses 2141 observations relating to 260 startups. In specification 3, we also control for any unobserved industry effects using lagged ISM patents. ${ }^{19}$ In specification 4 we add an interaction term between marketing ability and technical ability. All specifications in Table 4 report standard errors clustered at the firm level.

\section{$<$ Insert Table 4 here $>$}

We had hypothesized, in $\mathrm{H} 1$ and $\mathrm{H} 3$, that technological and marketing capability respectively should improve performance. The results in Table 4 confirm this. From specification 1, the coefficient of technical capability is significant and large. This means that, for a firm with technical capability one standard deviation higher than the mean, the relative hazard of exit is about 21 percent lower (relative to the baseline hazard).

\footnotetext{
${ }^{18}$ Other specifications such as Cox proportional hazard regressions yield qualitatively similar results.

${ }^{19} \mathrm{We}$ also estimated a random effect logit specification, which relaxes the assumption that observations for a firm are independent over time and found that the results are largely unchanged. A Hausman test that compares specification 1 with the random effect specification rejects the hypothesis that the coefficients are different $\left(\chi^{2-} 0.61\right.$; p-value 0.48$)$. 
Similarly, marketing ability also enhances performance: Startups with an additional sales executive have, on average, a 37 percent lower hazard of exit. ${ }^{20}$ Specification 2 shows that including size does not qualitatively affect our estimates, ${ }^{21}$ and neither does controlling for technical opportunity using lagged total patents (specification 3). Specification 4 shows that marketing and technical ability are complements. The coefficient of the interaction term is negative and significant. Put differently, for a firm with one additional sales executive, the impact of one standard deviation increase in technical ability on exit decreases by an additional $11 \% .^{22}$

In Table 5 we test how the values of technical and marketing ability are conditioned by the extent of supply of technology. To this end, we divide the sample into two sub-samples depending on whether technology supply is above the sample mean (high) or below it (low). Note that since we also want to explore how the complementarity between technical and marketing ability changes with increases in technology supply we prefer splitting the sample in high and low as opposed to using multiple interaction terms in the logit regressions. ${ }^{23}$ The results support $\mathrm{H} 2$ and $\mathrm{H} 4$. In specification 1 , we use the same independent variables as in Table 4. In specification 2, as before, we additionally control for technical opportunity. Finally, in specification 3, we include the interaction term between marketing ability and technical ability.

In Table 5A we use the estimated coefficients in specification 1 of Table 5 to show the estimated impact of technology supply on marketing and technical capabilities. When technology supply is "low", one-standarddeviation increase in a firm's technical ability is associated with a 76 percent decrease in the hazard of exit (relative to the baseline), whereas, when technology supply is "high", one-standard-deviation increase in a firm's technical capability decreases the relative hazard of exit by only 21 percent. The difference is

\footnotetext{
${ }^{20}$ Calculated as follows: The relative hazard is calculated as follows: A startup with 1 SD higher patents has about $2.46(=0.91 / 0.37)$ times more patents. Hence, the relative hazard for a startup with 1 SD more patents is (1-exp(-0.09))*2.46. An additional sales executive implies a 1.49 times increase in the number of sales executives. Hence, the relative hazard of exit for a startup with 1 additional sales executive is $(1-\exp (-0.29)) * 1.49$.

${ }^{21}$ A likelihood ratio test between specifications 1 and 2 reveals that the coefficients are not different from each other $\left(\chi^{2}-2.28 ; \mathrm{p}-\right.$ value - 0.34) and a similar test between specifications 1 and 3 also suggest that the coefficient are not different from each other $\left(\chi^{2}-\right.$ 1.18 ; p-value -0.03).

${ }^{22}$ The interaction effect is calculated as $(1-\exp (-0.03)) * 1.49 * 2.46$.

${ }^{23}$ See Ai and Norton (2003), Hoetker (2007), and Zelner (2009) for issues that relate to the interpretation of interaction terms in logit models. 
statistically significant (at 5 percent level) and meaningful (55 percent). These results confirm that an increase in the supply of technology diminishes the marginal value of internal technology capability.

However, an increase in external technology supply accentuates the value of marketing capability. In the "high" sample the marginal effect of one additional sales executive is a 77 percent decrease in the relative hazard of exit, whereas a similar increase in the "low" sample is associated with only a 36 percent decrease in the relative hazard of exit. This implies that when the extent of technology supply changes from being "low" to "high" the marginal effect of a one-standard-deviation increase in marketing ability increases by a statistically significant (at 10 percent) 41 percent.

\section{<Insert Table 5 here>}

Specification 3 shows that the coefficient of the interaction term between technical ability and marketing ability increases in (absolute) magnitude when the supply of external technology changes from "high" to "low" (-0.02 vs. -0.08). In other words, as the supply of external technology increases, the measured complementarity between internal technical capability and marketing decreases. One must interpret this finding with caution. As we have shown, firms increase their use of external technology as its supply increases, and reduce the reliance upon internal technology. As a result, even if technical capability and marketing capability are complements, the lower reliance upon technical capability may well result in a lower measured complementarity.

$<$ Insert Table 5A here>

\section{Robustness checks}

Results using cash-outs as measure of performance:

Since firm survival may not adequately proxy firm performance, we explore the robustness of our principal results using an alternative measure of performance, namely cash-outs. In many high-technology industries, cashing out via successful acquisition by another firm or an IPO is a common indicator sign of success (Arora and Nandkumar, 2009).

In specification 1 of Table 6, using cash-outs as a dependent variable, we replicate specification 1 of Table 4. In specification 2 of Table 6, we replicate specification 2 of table 5 . The results confirm that both 
technical and marketing abilities enhance firm performance. While a one-standard-deviation increase in a firm's technical ability is associated with about 1.06 times increase in hazard of cashing out, an additional sales executive implies about a 65 percent increase in the hazard of cashing out, supporting both $\mathrm{H} 1$ and $\mathrm{H} 3$.

\section{$<$ Insert Table 6 here>}

In specification 2 of Table 6 , we replicate specification 1 of Table 5. Our results are qualitatively similar to those shown in Table 5. While an increase in the supply of external technology diminishes the value of technical capability, it enhances the value of marketing ability for performance. When technology supply is "low", one additional sales executive increases the hazard of cashing out by only 14 percent, whereas when the supply of technology is "high", one additional sales executive increases the hazard of cashing out by 87 percent. Consistent with our earlier results, markets for technology appear to diminish the value of technical ability as a source of competitive advantage. When tech supply is "low", a startup with one-standard-deviation-higher technical ability has approximately 2.23 times higher hazard of cashing out. However, when supply of technology is "high", a startup with one-standard-deviation-higher technical ability has a cash-out hazard that is only 1.11 times higher. We also get qualitatively similar results if we use growth in employment in the first three years of operation as an alternative measure of performance. Space constraints prevent us from reporting these here, but these and other results of the robustness checks reported here are available upon request.

Other Robustness Checks: Our results are also robust to alternative measures for other key variables. For instance, we get even stronger results if we use the lagged stock of patents of the firm as our measure of the technical capability of the firm and the lagged stock of IT trademarks as our measure of the marketing capability of the firm. Similarly, our results are largely unchanged if we use the lagged stock of non-producer patents as the measure of technology supply. Our conclusions are also unchanged if we use the number of specialized technology licensors as the measure of technology supply.

It is plausible that university professors lack general business skills and hence may not recognize the importance of marketing for better performance. We find that our principal results are unchanged if we 
controlled for university startups. ${ }^{24}$ Also, we find that our principal results are qualitatively similar even when we control for whether a focal startup sold to the defense industry or government at any time during its tenure in the ISM using a government contractor dummy.

Other potential sources of bias: Two of our key independent variables, namely technical ability and marketing ability, are measured at the time of entry and thus vary across firms but not over time. Despite our extensive controls for the background and education of the founders, it is possible that these are correlated with unobserved factors that drive firm performance. For instance, entrants with more patents may attract venture capital, thereby improving performance. Similarly, better capitalized firms may be able to afford more sales executives. Both would result in a positive effect on performance. As well, the measures of technical and marketing abilities could pick up unobserved differences in firm quality. For instance, high-quality founders may be more likely to file patents or hire sales executives at the time of founding. Furthermore, founders of better quality might also start up better performing firms. However, none of the aforementioned situations should result in the observed pattern of interaction, wherein increases in the supply of technology enhance the value of marketing ability but diminish that of technical ability.

A related issue is that our measure of marketing ability may additionally capture unobserved differences in general managerial capabilities that are particularly important for small firms. In our regressions we use a variety of controls that also control for differences in managerial ability of firms - we control not only for the amount of work experience but also for the nature of prior experience of the founder. That our results survive even with these controls provides us with confidence that our stated effect is likely to be how markets for technology enhance marketing capability rather than how it changes the value of general managerial capability for better performance. However, how conditions in the markets for technology influence the relative importance of managerial capability is an interesting question and is a potentially interesting avenue for future research.

\footnotetext{
${ }^{24}$ Our principal results are qualitatively unaltered even when we re-estimated our regressions after removing university startups from the sample. 
Similarly, our measure of technology supply could plausibly capture differences in technical opportunity. This could affect exit probabilities and perhaps even the probability of cash-out. However, when technical opportunity is high, technical capability should be more valuable, not less. As well, measured technology supply could be correlated with demand. Once again, this should increase the value of technical ability rather than decrease it. Thus, our results are unlikely to be the driven by unobserved differences in technical opportunity, demand conditions, or the quality of founders.

Greater supply of external technology can lower entry barriers, enabling less efficient firms, with lower resources and capabilities to enter. ${ }^{25}$ As a result, firms with lower marketing and technical capabilities may enter. Clearly, such firms are at a greater risk of exit as well, as is clear from table 3 as well. Indeed, when the technology supply is "low" (university patents lesser than mean number of university patents) the average technical capability is 0.74 whereas when technology supply was "high" the average technical capability is 0.22 . However, when technology supply is low the average marketing capability is 0.35 , and is 0.88 when technology supply is "high".

The question is how this should affect the performance. If indeed the problem is that technology markets enable technically less capable firms to enter, then we should see technical capability enhancing performance (on average). Our results show the opposite. Technically less capable firms are more likely to enter and also more likely to flourish when technology supply is high. Therefore, while technology supply does lower entry barriers, this should not affect the estimated effect of technology and marketing capability of the firm on its performance. ${ }^{26}$

Finally, we see similar patterns when we use cash-outs to measure performance, rather than survival. On balance, it seems unlikely that our results are driven by lower entry thresholds due to greater technology supply. As also briefly discussed earlier, internal and external technology may in fact be complements rather than substitutes because higher technological ability may confer greater absorptive capacity, enabling the firm to benefit more from better functioning markets for technology. In our setting, absorptive capability is likely

\footnotetext{
${ }^{25}$ We are grateful to an anonymous reviewer for helpful discussion.

${ }^{26}$ If the relationship between marketing capability and performance has significant non-linearities, then raising the threshold level of marketing capability required to enter the industry may change the estimated coefficient, but one cannot say whether we are over or underestimating the true coefficient. A similar observation applies to the case of technical capability. 
captured by measures of the technical backgrounds of the founder and measures of work experience, making

this concern less salient. A majority of the startups in our sample had founders with experience either in the ICT or the ISM itself, and nearly half of the startups had at least one founder with an engineering $\mathrm{PhD}$. As a robustness check (not reported here), we used the past patents of the founders as a separate measure of absorptive capacity and found similar results.

\section{DISCUSSION AND CONCLUSION}

In this paper we study how variations in the supply of technology influence the relative value of marketing and technical abilities. We argue that whereas an increase in technology supply should enhance the potency of a firm's marketing ability in improving performance, it should reduce the potency of a firm's technical ability.

We show that even after controlling for initial size at entry and for the prior work experience of the founder, as well as for the age of the submarket and for market tenure, the capabilities a startup brings to the market are important for performance. Both marketing capability and technical capability enhance survival, cash-outs, and growth. Simply put, startup firms benefit from both technical and marketing capability. Moreover, consistent with our expectations, we find that these capabilities are complementary. A direct implication for strategy is that investments in developing technical capability must be balanced with corresponding investments in marketing.

However, our principal focus is to understand the factors that condition the value of these capabilities. This is therefore one of very few papers (to our knowledge) to explicitly examine how the value of a firm's resources and capabilities is contingent on the environment. Apart from identifying a specific contingency, we provide theoretical arguments of the underlying mechanism of how the contingency influences the value of internal capabilities for superior performance. We show that an external supply of technology diminishes the value of a capability that enables firms to produce a substitute (internal technical capability) and enhances the value of a capability that enables it to produce a complement (marketing capability) as a source of strategic 
advantage. Our results appear robust to a number of different empirical measures of technology supply, technical capability, and marketing capability.

Over the past few years, the RBV has pointed to the importance of capabilities, including both static and dynamic capabilities in conditioning firm performance. For new firms and startups, in particular, this is a first order question because it guides where scarce resources must be invested. This logically leads to the focus of our paper, namely how the relative importance of different capabilities change as the external environment changes. In particular, as markets of inputs, such as technology develop, how does this change the impact of (internal) technical capability on performance? Further, how does the impact of marketing capability, which is complementary to technical capability, change with an increase in externally supplied technology.

Even for a given capability, such changes in environment can have different effects depending upon the strategy of the firm. As the literature has already emphasized, for firms that aim to monetize their technical capability by licensing, the growth of a market for technology can increase the value of technical capability. Simply put, these firms can specialize in licensing technology. The majority of firms, however, aim to produce, not license. For such firms, an increase in the supply of external technology will make internal technical capability less valuable and less important to their competitive advantage. Conversely, marketing capability may be more important in differentiating a firm from its competitors, and thus be more valuable.

The obvious implication for managers is that investments in capability must be made with an eye to the environment. When the fruits of a capability can be traded on a market, managers face a clear choice. Either, they can choose to sell the fruits of their capability to others, or, as is more often the case, they can scale down the use of internal capability and rely more extensively on the externally supplied inputs. For instance, as IT outsourcing became more prevalent, thanks in part to the greater standardization of IT processes, internal IT capability because less important as a source of competitive advantage for telecom firms. Indeed, new entrants such as Bharti Telecom have outsourced the operation of their entire network and IT systems to partners such as Ericson and IBM, and chosen to rely more heavily on other capabilities, including marketing, distribution, and customer service. Similarly, as chemical process technologies became more readily available from engineering contractors, leading chemical firms such as Eastman Chemicals, that had very significant technical capability in 
new process development, retrenched, and focused instead on a smaller set of technologies where they judged

their internal technical capability to be a source of differentiation.

Clearly the nature of the contingency analyzed in this paper is just one of many types of contingencies that might influence the value of resources and capabilities. We nonetheless hope that this paper spurs further research that advances the understanding of how the natures of different types of contingencies influence the value of a firm's resources for superior performance.

\section{ACKNOWLEDGEMENTS}

This paper is based on a chapter of Nandkumar's $2008 \mathrm{PhD}$ dissertation at the Heinz College, Carnegie Mellon University. The paper has improved in response to comments from anonymous reviewers of the Journal. We are also grateful to seminar participants at Duke, UCLA, and Emory for helpful comments.

\section{REFERENCES}

Agarwal R, Gort M. 2002. Firm and product life cycles and firm survival. American Economic Review: 184190.

Agarwal R, Echambadi R, Framco AM, Sarkar MB. 2004. Transfer through inheritance: Spin-out generation, development, and survival. Academy of Management Journal 47(4): 501-522.

Agrawal A. 2006. Engaging the inventor: Exploring licensing strategies for university inventions and the role of latent knowledge. Strategic Management Journal: 27:63-79.

Amit R, Schoemaker PJH. 1993. Strategic assets and organizational rent. Strategic Management Journal 14(1): 33-46.

Ai C, Norton EC. 2003. Interaction terms in logit and probit models Economics Letters 80(1): 123-129.

Arora A, Ceccagnoli M. 2006. Patent protection, complementary assets, and firms' incentives for technology licensing. Management Science 52: 292-308.

Arora A, Fosfuri A, Gambardella A. 2001a. Markets for technology: The economics of innovation and corporate strategy. MIT Press: Cambridge, MA.

Arora A, Fosfuri A, Gambardella A. 2001b. Specialized technology suppliers, international spillovers and investments: Evidence from the chemical industry. Journal of Development Economics 65(1): 31-54.

Arora, A, Gambardella A. 1994. The changing technology of technological change: general and abstract knowledge and the division of innovative labour. Research Policy 23(5): 523-532.

Arora, A, Gambardella A. 1990. Complementarity and external linkages: the strategies of the large firms in biotechnology. Journal of Industrial Economics 38(4): 361-379.

Arora A, Nandkumar, A. 2009. Cash-out or flame-out! Opportunity cost and entrepreneurial strategy: Theory, and evidence from the information security industry, NBER working paper.

Audretsch DB, Mahmood T. 1995. New firm survival: New results using a hazard function. The Review of Economics and Statistics: $97-103$.

Barney J. 1991. Firm resources and sustained competitive advantage. Journal of Management 17(1): 99-120.

Barney J. 1986. Strategic factor markets: Expectations, luck, and business strategy. Management Science 32(10): 1231-1241.

Barney J. 2001. Resource-based theories of competitive advantage: A ten-year retrospective on the resourcebased view. Journal of Management 27(6): 643-650.

Barney J, Arikan A. 2001. The resource-based view: origins and implications. In Handbook of Strategic

Management, Hitt MA, Freeman RE, Harrison JS (eds). Blackwell: Oxford, U.K.; 124-188.

Blanchflower DG, Oswald AJ. 1998. What makes an entrepreneur? Journal of Labor Economics 16(1): 26-60. 
Brush TH, Artz KW. 1999. Toward a contingent resource-based theory: The impact of information asymmetry on the value of capabilities in veterinary medicine. Strategic Management Journal 20(3): 223-250.

Carroll GR, Bigelow LS, Seidel ML, Tsai LB. 1996. The fates of de novo and de alio producers in the American automobile industry 1885-1981. Strategic Management Journal 17: 117-137.

Cassiman B, Veugelers R. 2006. In Search of Complementarity in Innovation Strategy: Internal R\&D and External Knowledge Acquisition. Management Science 52(1):68-82.

Cockburn IM, MacGarvie M. 2007. Patents, Thickets, and the Financing of Early-Stage Firms: Evidence from the Software Industry. NBER Working Paper.

Dierickx I, Cool K. 1989. Asset stock accumulation and sustainability of competitive advantage. Management Science 35(12): 1504-1511.

Dosi G, Teece DJ. 1993. Organizational Competencies and the Boundaries of the Firm. University of California at Berkeley, Center for Research in Management.

Dunne T, Roberts MJ, Samuelson L. 1988. Patterns of firm entry and exit in US manufacturing industries. The RAND Journal of Economics: 495-515.

Evans DS. 1987. The relationship between firm growth, size, and age: Estimates for 100 manufacturing industries. The Journal of Industrial Economics: 567-581.

Foster RN. 1986. Attacker's Advantage. Summit books.

Gambardella A, Giarratana MS. 2007. General technologies, product-market fragmentation and the market for technology: Evidence from the software security industry. Draft, Bocconi University.

Gans JS, Hsu DH, Stern S. 2002. When does start-up innovation spur the gale of creative destruction? The RAND Journal of Economics 33(4): 571-586.

Giarratana MS, 2004. The Birth of a New Industry: Entry by Start-Ups and the Drivers of Firm Growth. The Case of Encryption Software. Research Policy 33: 787-806.

Hannan MT, and Freeman J. 1984. Structural inertia and organizational change. American Sociological Review 49(2): 149-164

Hansen GS, Wernerfelt B. 1989. Determinants of firm performance: The relative importance of economic and organizational factors. Strategic Management Journal 10(5): 399-411.

Helfat CE. 1997. Know-how and asset complementarity and dynamic capability accumulation: The case of R\&D. Strategic Management Journal 18(5):339-360.

Helfat CE, Lieberman MB. 2002. The birth of capabilities: market entry and the importance of pre-history. Ind Corp Change 11(4): 725-760..

Henderson R, Cockburn I. 1994. Measuring competence? Exploring firm effects in pharmaceutical research. Strategic Management Journal 15: 63-84.

Henderson RM, Clark KB. 1990. Architectural innovation: The reconfiguration of existing product technologies and the failure of established firms. Administrative Science Quarterly 35:1.

Hoetker G. 2007. The Use of logit and probit models in strategic management research: Critical issues. Strategic Management Journal 28: 331-343

Jensen R, Thursby M. 2001. Proofs and prototypes for sale: The licensing of university inventions. American Economic Review 91(1): 240-259

Katila R, Shane S. 2005. When does lack of resources make new firms innovate? The Academy of Management Journal 48(5): 814-829.

King AA, Tucci CL. 2002. Incumbent entry into new market niches: the role of experience and managerial choice in the creation of dynamic capabilities. Management Science: 171-186.

Klepper S. 2002. The capabilities of new firms and the evolution of the US automobile industry. Ind Corp Change 11(4): 645-666. doi:10.1093/icc/11.4.645.

Klepper S, Simons KL. 2000. Dominance by birthright: Entry of prior radio producers and competitive ramifications in the U.S. television receiver industry. Strategic Management Journal 21(10/11): $997-$ 1016. doi:10.2307/3094424.

Klepper S, and Sleeper S. 2005. Entry by Spinoffs. Management Science: 51(8):1291-1306.

Leonard-Barton D. 1992. Core capabilities and core rigidities: A paradox in managing new product development. Strategic Management Journal 13 : 111-125. 
Lieberman MB. 1987. Patents, learning by doing, and market structure in the chemical processing industries. International Journal of Industrial Organization 5(3): 257-276.

Lieberman MB. 1989. The learning curve, technological barriers to entry, and competitive survival in the chemical processing industries. Strategic Management Journal 10(5): 431-447.

Lippman SA, Rumelt RP. 1982. Uncertain imitability: An analysis of interfirm differences in efficiency under competition. The Bell Journal of Economics 13(2): 418-438.

Makadok R. 1999. Interfirm differences in scale economies and the evolution of market shares. Strategic Management Journal 20(10): 935-952..

Martin X, Mitchell W. 1998. The influence of local search and performance heuristics on new design introduction in a new product market. Research Policy 26(7-8): 753-771.

Mata J, Portugal P. 1994. Life duration of new firms. The Journal of Industrial Economics: 227-245.

McGahan AM, Porter ME. 1997. How much does industry matter, really? Strategic Management Journal 18 (July): 15-30.

Miller D, Shamsie J. 1996. The resource-based view of the firm in two environments: The Hollywood film studios from 1936 to 1965. The Academy of Management Journal 39(3): 519-543.

Mitchell W. 1989. Whether and when? Probability and timing of incumbents' entry into emerging industrial subfields. Administrative Science Quarterly 34(2): 208-230.

Mitchell W. 1991. Dual clocks: Entry order influences on incumbent and newcomer market share and survival when specialized assets retain their value. Strategic Management Journal 12: 85-100.

Penrose, E. T. (1959). The Theory of the Growth of the Firm. New York: John Wiley.

Peteraf MA. 1993. The cornerstones of competitive advantage: A resource-based view. Strategic Management Journal 14(3): 179-191.

Robins J, Wiersema MF. 1995. A Resource-based approach to the multibusiness firm: Empirical analysis of portfolio interrelationships and corporate financial performance. Strategic Management Journal 16(4): 277-299.

Rumelt RP. 1991. How much does industry matter? Strategic Management Journal 12(3): 167-185.

Thompson P. 2005. Selection and firm survival: Evidence from the shipbuilding industry, 1825-1914. Review of Economics and Statistics 87(1): 26-36.

Tripsas M. 1997. Unraveling the process of creative destruction: Complementary assets and incumbent survival in the typesetter industry. Strategic Management Journal 18: 119-142.

Utterback JM, Abernathy WJ., 1975. A dynamic model of process and product innovation. Omega 33(6): 639656.

Wernerfelt B. 1984. A Resource-based view of the firm. Strategic Management Journal 5(2): 171-180.

Zajac EJ, Kraatz MS, Bresser RKF. 2000. Modeling the dynamics of strategic fit: A normative approach to strategic change. Strategic Management Journal 21(4): 429-453.

Zelner BA. 2009. Using simulation to interpret results from logit, probit, and other nonlinear models. Strategic Management Journal 30(12): 1335-1348. 
Tables:

Table 1A: ISM technology and product map

Encryption

Image-matching

Pattern matching

Single Sign-On

\begin{tabular}{lccc}
\hline $\begin{array}{l}\text { Authentication } \\
\text { Antivirus }\end{array}$ & $\mathrm{X}$ & $\mathrm{X}$ & $\mathrm{X}$ \\
$\begin{array}{l}\text { Encryption products } \\
\text { Hardware }\end{array}$ & $\mathrm{X}$ & $\mathrm{X}$ & $\mathrm{X}$ \\
$\begin{array}{l}\text { Firewall } \\
\text { Network (VPN) }\end{array}$ & $\mathrm{X}$ & $\mathrm{X}$ \\
$\begin{array}{l}\text { Parental control } \\
\text { Consulting }\end{array}$ & & & \\
\hline
\end{tabular}

Table 1B: Patenting, and licensing by submarket type

\begin{tabular}{cccccc}
\hline Submarket & $\begin{array}{c}\text { Share of } \\
\text { entrants }^{+}\end{array}$ & $\begin{array}{c}\text { Percentage of } \\
\text { entrants with in- } \\
\text { licensed } \\
\text { technology }\end{array}$ & $\begin{array}{c}\text { Patents as } \\
\text { percent of total } \\
\text { security patents }\end{array}$ & $\begin{array}{c}\text { Percentage of } \\
\text { patents held by } \\
\text { universities }\end{array}$ & $\begin{array}{c}\text { Std. dev. in number } \\
\text { of university } \\
\text { patents, 1989-2004 }\end{array}$ \\
\hline Authentication & 0.32 & 47 & 67 & 25 & 69.06 \\
Antivirus & 0.17 & 16 & 23 & 1 & 3.08 \\
Encryption products & 0.03 & 41 & 2 & 49 & 82.86 \\
Hardware & 0.06 & 13 & 14 & 2 & 2.98 \\
Firewall & 0.09 & 23 & 30 & 39 & 2.76 \\
Network & 0.24 & 50 & 1 & 0 & 50.05 \\
Parental control & 0.07 & 5 & & 2 & 5.52
\end{tabular}

${ }^{\mathrm{a}}$ Based on a subset of 120 entrants for which information could be gathered on licensing.

${ }^{+}$Based on the first submarket of entry. The remaining firms provide consulting services. 
Table 2: Description of measures used

\begin{tabular}{|c|c|c|c|c|c|}
\hline Variable & Description & $\mathbf{N}$ & $\begin{array}{c}\text { Unit of } \\
\text { observation }\end{array}$ & Mean & Std. Dev. \\
\hline Tech supply & $\begin{array}{l}\text { Log of } 1+\text { weighted security } \\
\text { technology patents by universities } \\
\text { and government agencies, lagged }\end{array}$ & 2219 & $\begin{array}{c}\text { submarket } \mathrm{x} \\
\text { year }\end{array}$ & 1.28 & 1.42 \\
\hline Tech ability & $\begin{array}{l}\text { Log of } 1+\# \text { of weighted security } \\
\text { patents held at entry. }\end{array}$ & 2219 & Firm & 0.37 & 0.91 \\
\hline Marketing ability & $\log$ of $1+\#$ sales executives at entry & 2219 & Firm & 0.67 & 0.42 \\
\hline Scale & Log of $1+\#$ employees at entry & 2141 & Firm & 3.58 & 1.44 \\
\hline Cash-out & $\begin{array}{l}=1 \text { if the startup was acquired on } \\
\text { favorable terms or had an IPO }\end{array}$ & $2219^{\mathrm{a}}$ & Firm & 0.03 & 0.16 \\
\hline Failure & $\begin{array}{l}=1 \text { if the startup had a distress sale or } \\
\text { went out of business completely }\end{array}$ & $2219^{b}$ & Firm & 0.03 & 0.17 \\
\hline Work experience & $\begin{array}{l}\text { Log of } 1+\# \text { years of work experience } \\
\text { of the main founder }\end{array}$ & 2141 & firm & 0.99 & 1.33 \\
\hline PhD. Dummy & $\begin{array}{l}=1 \text { if founder had a PhD. degree in } \\
\text { engineering, computer science, or } \\
\text { mathematics }\end{array}$ & $2219^{c}$ & Firm & 0.10 & 0.30 \\
\hline EE-CS dummy & $\begin{array}{l}=1 \text { if founder had an electrical } \\
\text { engineering or computer science } \\
\text { degree }\end{array}$ & $2219^{c}$ & Firm & 0.33 & 0.47 \\
\hline Masters dummy & $\begin{array}{l}=1 \text { if the founder had a master's } \\
\text { degree which is in neither computer } \\
\text { science nor electrical engineering }\end{array}$ & $2219^{c}$ & Firm & 0.26 & 0.41 \\
\hline Bachelors dummy & $\begin{array}{l}=1 \text { if the founder had a bachelor's } \\
\text { degree }\end{array}$ & $2219^{c}$ & Firm & 0.21 & 0.46 \\
\hline Submarket age & $\begin{array}{l}\text { Age of the industry measured from } \\
1970\end{array}$ & 2219 & Submarket & 8.87 & 5.68 \\
\hline ISM tenure & Current year minus ISM entry year & 2219 & Firm & 6.88 & 4.94 \\
\hline User startup & $\begin{array}{l}=1 \text { if principal founder is from non- } \\
\text { ICT firm }\end{array}$ & 2219 & Firm & 0.11 & 0.31 \\
\hline ICT startup & $\begin{array}{l}=1 \text { if principal founder is from an ICT } \\
\text { firm }\end{array}$ & 2219 & Firm & 0.48 & 0.5 \\
\hline Spinoff & $\begin{array}{l}=1 \text { if principal founder is from an } \\
\text { ISM firm }\end{array}$ & 2219 & Firm & 0.05 & 0.22 \\
\hline $\begin{array}{l}\text { Period dummy } \\
\text { variables }\end{array}$ & $\begin{array}{l}\text { Three dummy variables that indicate } \\
\text { if the year of observation is } 1980- \\
1995,1996-2000 \text {, or } 2001-2004\end{array}$ & 2219 & Year & & \\
\hline Tech Opportunity & $\begin{array}{l}\text { Log of } 1+\text { lagged industry ISM } \\
\text { patents (forward citation weighted) }\end{array}$ & 2219 & Year & 2.76 & 3.40 \\
\hline
\end{tabular}

${ }^{\mathrm{a}}$ The cash-out rate is 0.21 with a std. dev. of $0.40 .{ }^{\mathrm{b}}$ The failure rate is 0.23 with a standard deviation of 0.44 . The proportion of start-ups by: PhD is 0.12 (std. dev. = 0.30); EE or Comp. Sci. graduates is 0.39 (std..dev. 0.48); Other masters is 0.15 (std..dev. 0.42); Bachelors degree is 0.24 (std..dev. 0.48). About 9 percent of the founders do not have any college degrees. 
Table 3A

Probability of Exit By Technology Supply (University Patents) and Technical Capability (Security Patents) Tech Supply

\begin{tabular}{cccc}
\hline Tech Ability & \multirow{2}{*}{ Low (A) } & High (B) & B-A \\
\hline Low & 0.26 & 0.28 & 0.02 \\
$(1)$ & $(0.04)$ & $(0.03)$ & $(0.05)$ \\
\hline High & 0.11 & 0.25 & 0.14 \\
$(2)$ & $(0.08)$ & $(0.14)$ & $(0.15)$ \\
\hline$(2)-(1)$ & -0.15 & -0.03 & \\
& $(0.10)$ & $(0.08)$ & \\
\hline \hline
\end{tabular}

Notes: $\mathrm{N}=270$. High and Low categories are above and below the mean. Standard errors are in parentheses.

Table 3B

Probability Of Exit By Technology Supply (University Patents) And Marketing Capability (sales executives)

\begin{tabular}{cccc}
\hline \multicolumn{4}{c}{ Tech Supply } \\
\hline $\begin{array}{c}\text { Marketing } \\
\text { Ability. }\end{array}$ & Low (A) & High (B) & B-A \\
\hline Low & 0.23 & 0.33 & 0.10 \\
$(1)$ & $(0.07)$ & $(0.03)$ & $(0.08)$ \\
\hline High & 0.18 & 0.20 & 0.02 \\
$(2)$ & $(0.05)$ & $(0.06)$ & $(0.07)$ \\
\hline$(2)-(1)$ & -0.05 & -0.13 & \\
& $(0.09)$ & $(0.07)$ & \\
\hline
\end{tabular}

Notes: $\mathrm{N}=270$. High and Low categories are above and below the mean. Standard errors are in parentheses. 
Table 4: Logit regressions, dependent variable= FAILURE

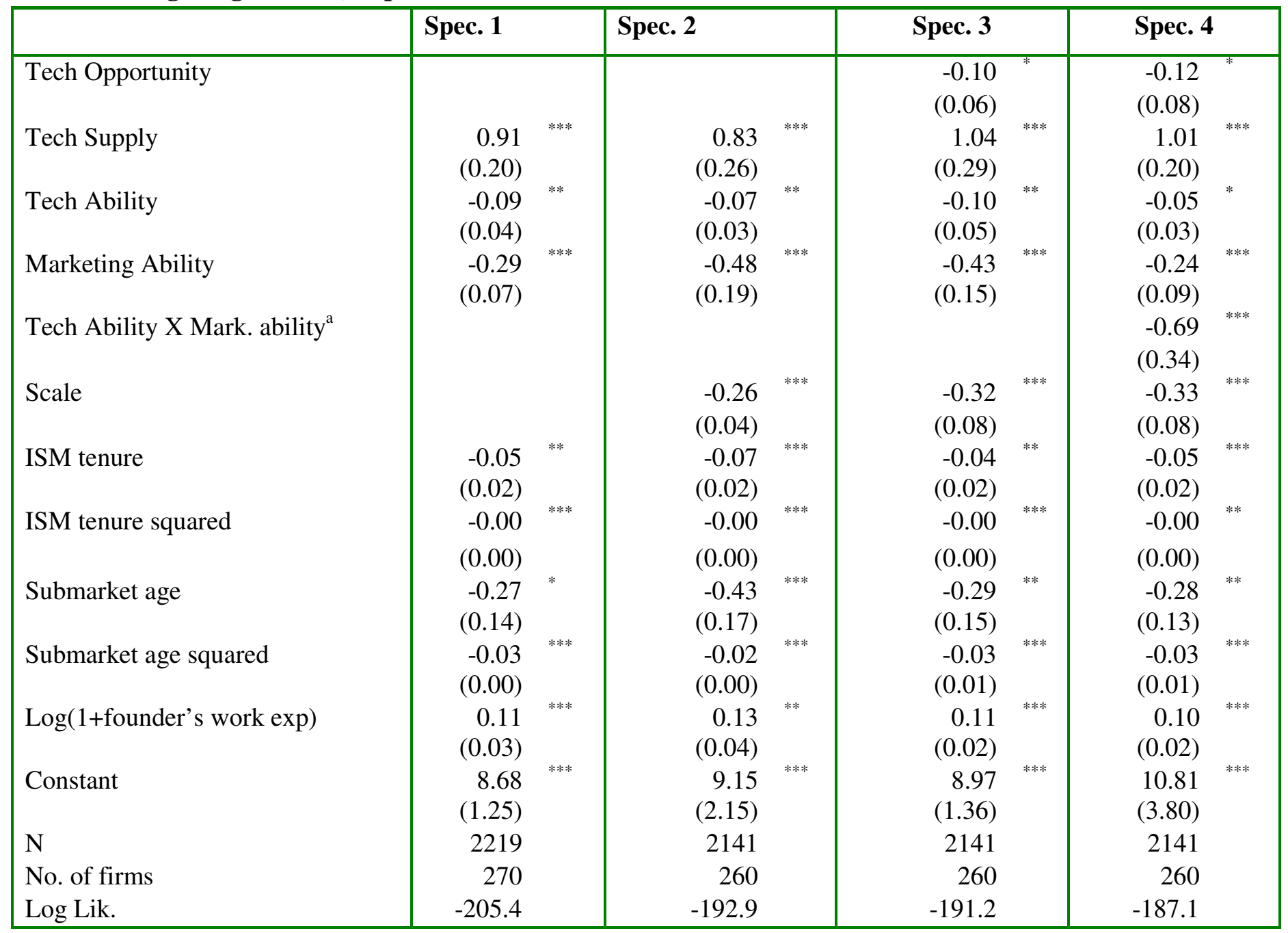

Notes: ***Significant at 1 percent. $* *$ Significant at 5 percent. * Significant at 10 percent. ${ }^{a}$ Marginal effect of the interaction term calculated using stata's inteff command is $-0.03(0.01)^{*}$. Standard errors cluster corrected by firm.

The unit of observation is firm and year.

All specifications include 7 submarket controls, 3 startup type controls, 4 founder education controls, and 2 cohort controls. Founder education controls consist of the following binary variables: PhD, Masters, Bachelors, and CS-EE. Startup type controls consist of the following binary variables: ICT startup, user startup, and spinoff. Submarket controls consist of the following binary variables: encryption product, network security, authentication, firewalls, antivirus, spam control, and hardware submarkets (consulting is the residual category). Cohort controls consist of the following binary variables: Internet-boom years and Post-bubble. 
Table 5: Logit regressions of failure, by high and low university patents

\begin{tabular}{|c|c|c|c|c|c|c|c|c|c|c|c|c|}
\hline \multirow[b]{3}{*}{ Tech. Opportunity } & \multicolumn{4}{|c|}{ Spec. 1} & \multicolumn{4}{|c|}{ Spec. 2} & \multicolumn{4}{|c|}{ Spec. 3} \\
\hline & $\begin{array}{r}\text { High uni } \\
\text { Patents }\end{array}$ & & $\begin{array}{r}\text { Low uni } \\
\text { patents }\end{array}$ & & $\begin{array}{r}\text { High uni } \\
\text { Patents }\end{array}$ & $\begin{array}{l}\text { iiv. } \\
\text { ts }\end{array}$ & $\begin{array}{r}\text { Low un } \\
\text { patent }\end{array}$ & & $\begin{array}{l}\text { High un } \\
\text { Patent }\end{array}$ & & $\begin{array}{r}\text { Low un } \\
\text { patent }\end{array}$ & \\
\hline & & & & & $\begin{array}{c}-0.19 \\
(0.08)\end{array}$ & & $\begin{array}{l}-0.07 \\
(0.04)\end{array}$ & & $\begin{array}{l}-0.15 \\
(0.09)\end{array}$ & & $\begin{array}{l}-0.06 \\
(0.06)\end{array}$ & \\
\hline Tech. Ability & $\begin{array}{l}-0.09 \\
(0.03)\end{array}$ & *** & $\begin{array}{l}-0.37 \\
(0.16)\end{array}$ & & $\begin{array}{r}-0.09 \\
(0.07)\end{array}$ & & $\begin{array}{r}-0.31 \\
(0.10)\end{array}$ & & $\begin{array}{r}-0.05 \\
(0.04)\end{array}$ & & $\begin{array}{r}-0.25 \\
(0.04)\end{array}$ & **** \\
\hline Marketing Ability & $\begin{array}{c}-0.83 \\
(0.30)\end{array}$ & **** & $\begin{array}{r}-0.28 \\
(0.11)\end{array}$ & *** & $\begin{array}{r}-0.70 \\
(0.59)\end{array}$ & ** & $\begin{array}{c}-0.32 \\
(0.12)\end{array}$ & $* * *$ & $\begin{array}{r}-0.68 \\
(0.32)\end{array}$ & $* * * *$ & $\begin{array}{c}-0.11 \\
(0.10)\end{array}$ & \\
\hline Tech. ability X Mark. ability & & & & & & & & & $\begin{array}{r}-0.47 \\
(0.28)\end{array}$ & * & $\begin{array}{l}-2.13 \\
(0.64)\end{array}$ & *** \\
\hline Scale & $\begin{array}{l}-0.29 \\
(0.12)\end{array}$ & **** & $\begin{array}{r}-0.26 \\
(0.27)\end{array}$ & & $\begin{array}{r}-0.30 \\
(0.11)\end{array}$ & *** & $\begin{array}{r}-0.19 \\
(0.21)\end{array}$ & & $\begin{array}{l}-0.31 \\
(0.17)\end{array}$ & ** & $\begin{array}{l}-0.16 \\
(0.05)\end{array}$ & *** \\
\hline ISM tenure & $\begin{array}{l}-0.07 \\
(0.03)\end{array}$ & $* * *$ & $\begin{array}{l}-0.08 \\
(0.01)\end{array}$ & **** & $\begin{array}{l}-0.06 \\
(0.01)\end{array}$ & $* * *$ & $\begin{array}{c}-0.06 \\
(0.02)\end{array}$ & *** & $\begin{array}{l}-0.07 \\
(0.03)\end{array}$ & $* * *$ & $\begin{array}{l}-0.05 \\
(0.02)\end{array}$ & **** \\
\hline ISM tenure squared & $\begin{array}{l}-0.00 \\
(0.00)\end{array}$ & *** & $\begin{array}{r}-0.00 \\
(0.00)\end{array}$ & $*$ & $\begin{array}{r}-0.00 \\
(0.00)\end{array}$ & **** & $\begin{array}{l}-0.00 \\
(0.00)\end{array}$ & & $\begin{array}{r}-0.00 \\
(0.00)\end{array}$ & $* * *$ & $\begin{array}{l}-0.00 \\
(0.00)\end{array}$ & \\
\hline Submarket age & $\begin{array}{l}-0.66 \\
(0.05)\end{array}$ & *** & $\begin{array}{l}-0.29 \\
(0.02)\end{array}$ & *** & $\begin{array}{l}-0.60 \\
(0.28)\end{array}$ & ** & $\begin{array}{c}-0.23 \\
(0.05)\end{array}$ & $* * *$ & $\begin{array}{l}-0.42 \\
(0.21)\end{array}$ & ** & $\begin{array}{l}-0.26 \\
(0.01)\end{array}$ & *** \\
\hline Submarket age squared & $\begin{array}{l}-0.01 \\
(0.00)\end{array}$ & & $\begin{array}{c}-0.02 \\
(0.01)\end{array}$ & ** & $\begin{array}{l}-0.01 \\
(0.00)\end{array}$ & ** & $\begin{array}{l}-0.01 \\
(0.00)\end{array}$ & ** & $\begin{array}{l}-0.01 \\
(0.00)\end{array}$ & * & $\begin{array}{l}-0.01 \\
(0.00)\end{array}$ & $* *$ \\
\hline $\log (1+$ founder's work exp.) & $\begin{array}{r}0.26 \\
(0.13)\end{array}$ & ** & $\begin{array}{c}0.09 \\
(0.01)\end{array}$ & **** & $\begin{array}{r}0.26 \\
(0.14)\end{array}$ & ** & $\begin{array}{r}0.11 \\
(0.03)\end{array}$ & $* * *$ & $\begin{array}{r}0.22 \\
(0.10)\end{array}$ & ** & $\begin{array}{r}0.12 \\
(0.07)\end{array}$ & $*$ \\
\hline Constant & $\begin{array}{r}22.39 \\
(10.05)\end{array}$ & ** & $\begin{array}{c}32.88 \\
(18.34)\end{array}$ & & $\begin{array}{l}22.65 \\
(9.88)\end{array}$ & **** & $\begin{array}{r}31.53 \\
(16.61)\end{array}$ & * & $\begin{array}{r}23.72 \\
(11.96)\end{array}$ & $* * *$ & $\begin{array}{r}37.12 \\
(19.16)\end{array}$ & \\
\hline Comp.bet tech and mark. ability & & & & & & & & & $\begin{array}{r}-0.02 \\
(0.01)\end{array}$ & * & $\begin{array}{r}-0.08 \\
(0.02)\end{array}$ & *** \\
\hline $\mathrm{N}$ & 1059 & & 1082 & & 1059 & & 1082 & & 1059 & & 1082 & \\
\hline Submarket dummies ${ }^{+}$ & 4 & & 6 & & 4 & & 6 & & 4 & & 6 & \\
\hline Log Lik. & -176.5 & & -96.2 & & -175.3 & & -94.8 & & -172.8 & & -95.7 & \\
\hline
\end{tabular}

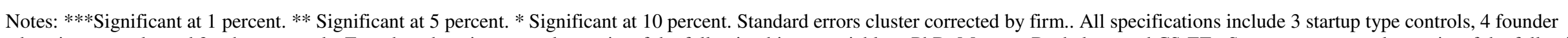

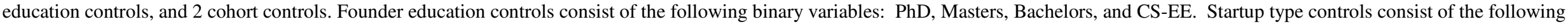

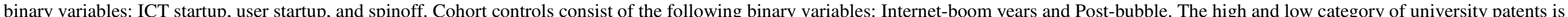

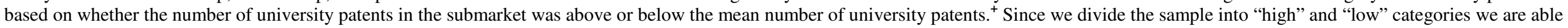
to estimate only 6 submarket dummies in the "low" category and 4 submarket dummies in the "high" category. 
Table 5A: Estimated impacts of one-std.-deviation increase in patents and one additional sales exec. on failure by "high" and "low" technology supply using estimates from Table 5, specification 1

Tech. supply

\begin{tabular}{cccc}
\hline & High (1) & Low (2) & Diff. impact (1)-(2) \\
\hline Technical capability & -0.21 & -0.76 & $\mathrm{H} 2$ \\
& $(0.07)$ & $(0.26)$ & $0.55^{* *}(0.27)$ \\
\hline Marketing capability & -0.77 & -0.36 & \multicolumn{2}{c}{$\mathrm{H} 4$} \\
& $(0.22)$ & $(0.12)$ & $-0.41^{*}(0.25)$ \\
\hline
\end{tabular}

Notes: Std. errors in parentheses, calculated using the delta method. The standard errors for relative hazards are calculated as $\exp (\hat{\beta}) * \overrightarrow{S E} *$ Sig. at 10 percent $* *$ Sig. at 5 percent; *** Sig. at 1 percent. 
Table 6: Logit regressions of with cash-out as measure of performance

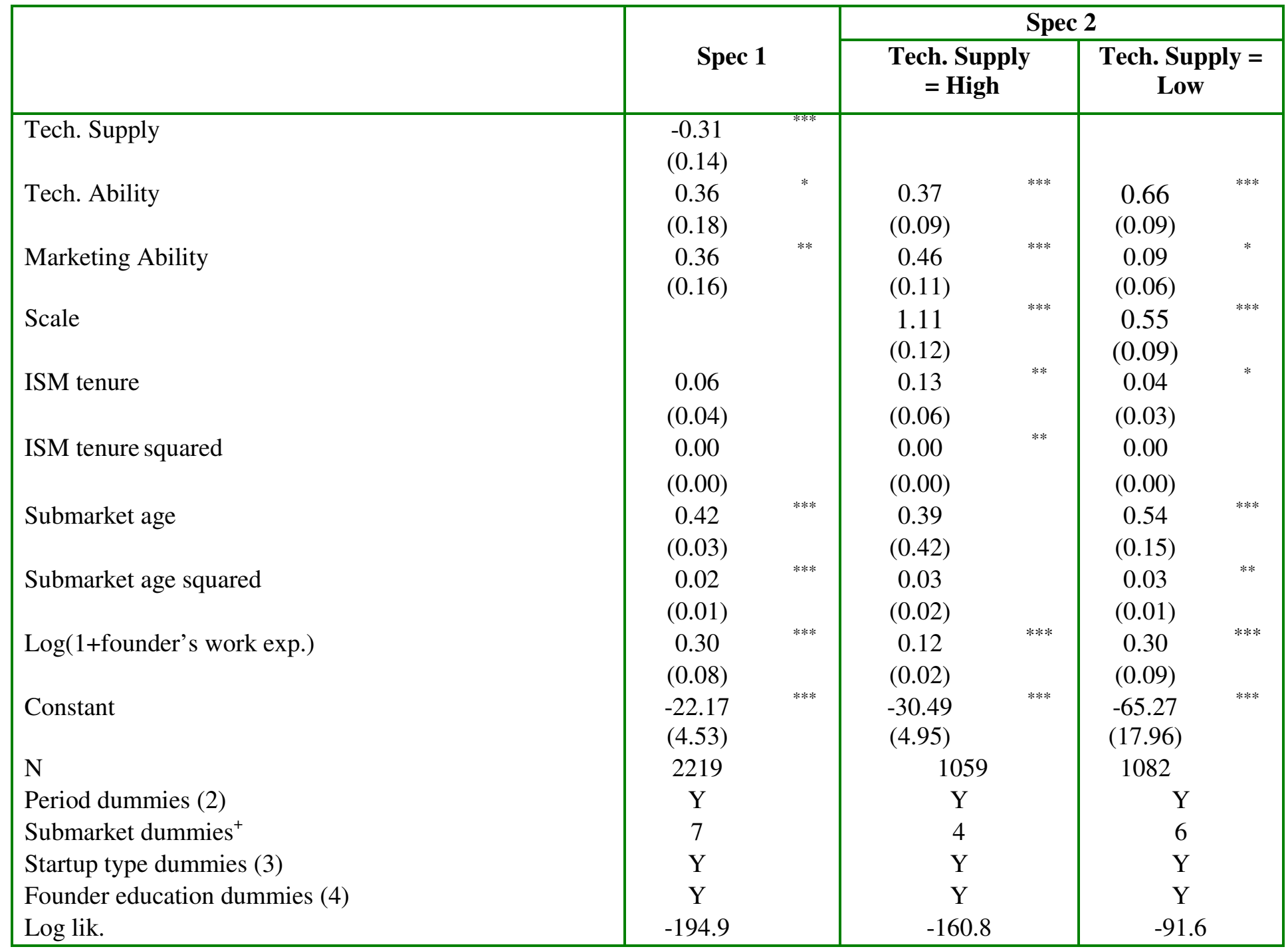

Notes: ***Significant at 1 percent. ** Significant at 5 percent. * Significant at 10 percent. Standard errors cluster corrected by firm. The unit of observation is firm and year. All specifications include 3 startup type controls, 4 founder education controls, and 2 cohort controls. Founder education controls consist of the following binary variables: PhD, Masters, Bachelors, and CS-EE. Startup type controls consist of the following binary variables: ICT startup, user startup, and spinoff. Cohort controls consist of the following binary variables: Internet-boom years and Post-bubble.

The high and low category of university patents is based on whether the number of university patents in the submarket was above or below the mean number of university patents. See also notes to Table 4.

+ Since we divide the sample into "high" and "low" categories we are able to estimate only 6 submarket dummies in the "low" category and 4 submarket dummies in the "high" category. 


\section{Appendix-1: Mapping of US.PTO subclasses to Information Security Submarkets}

\begin{tabular}{|l|l|}
\hline Submarket $^{*}$ & Most commonly cited US.PTO subclasses \\
\hline Encryption product & $380 / 1,380 / 39$ through $380 / 43,380 / 255,380 / 259$ through \\
& $380 / 261,380 / 264,380 / 270,380 / 277$ through $380 / 286$, \\
& $380 / 46,380 / 47,380 / 29,380 / 30$ and patent classes 709, \\
Authentication & 713 \\
& $380,726 / 1$ through $726 / 8,726 / 17,726 / 18,726 / 19,726 / 27$, \\
Hardware & $726 / 28$ through $726 / 30,726 / 31$ through $726 / 33$ \\
Parental control & $726 / 9,726 / 20,726 / 34,726 / 34,726 / 36$ \\
Network security & $726 / 26$ \\
Firewall & $380,726 / 22,726 / 33$ \\
Antivirus & $726 / 11$ through $726 / 16$ \\
\hline
\end{tabular}

* Consulting firms do not have any security patents. 